\title{
KESEDIAAN GURU SAINS SEKOLAH RENDAH TERHADAP PELAKSANAAN PEMBELAJARAN ABAD KE-21
}

\author{
${ }^{1}$ Azalida Tajudin, ${ }^{2}$ Norazilawati Abdullah \\ ${ }^{1,2}$ Fakulti Pembangunan Manusia, Universiti Pendidikan Sultan Idris \\ ${ }^{2}$ Pusat Penyelidikan Perkembangan Kanak-Kanak Negara (NCDRC) \\ 35900 Tanjong Malim, Perak \\ *emel : azalidaazalida61289@gmail.com
}

Received : 10 April 2018; Accepted : 26 Mei 2018; Published : 27 Jun 2018

\begin{abstract}
Abstrak
Kajian tinjauan ini dijalankan bertujuan mengkaji sejauh manakah kesediaan guru Sains dan sekolah rendah daripada aspek pengetahuan, kemahiran, minat dan sikap dalam melaksanakan pembelajaran abad ke-21 di Jasin. Kajian ini juga bertujuan untuk mengenalpasti adakah terdapatnya hubungan kesediaan guru Sains daripada segi penguasaan pengetahuan, kemahiran, minat dan sikap dengan pengalaman mengajar dan jantina. Seramai 115 orang guru telah dipilih secara rawak berstrata dalam menjayakan kajian ini. Instrumen yang digunakan dalam kajian ini ialah set soal selidik, skala likert 5 mata digunakan bagi tahap kesediaan dari segi pengetahuan, kemahiran, minat dan sikap. Data dianalisis menggunakan Statistical Package for Social Science (SPSS) version 20.0 dan ditunjukkan dalam frekuensi, min dan sisihan piawai. Dapatan hasil kajian menunjukkan tahap kesediaan guru Sains sekolah rendah di Jasin dari segi pengetahuan,sikap, kemahiran dan minat berada pada tahap tinggi. Melalui Ujian-t dan ANOVA menunjukkan tidak terdapat hubungan yang signifikan antara pengetahuan, sikap, kemahiran dan minat dengan jantina dan pengalaman mengajar guru. Akhirnya penyelidik mengemukakan beberapa cadangan kajian lanjutan untuk dijalankan oleh penyelidik yang akan datang.
\end{abstract}

Kata kunci Pengetahuan, Kemahiran, Minat, Sikap, Sains, Pembelajaran Abad Ke-21.

\begin{abstract}
This study aimed to examine that aspects of teachers' readiness, mastery of knowledge and skills, interest and attitude in implementing the $21^{\text {st }}$ century learning. This study was conducted in the Jasin District. This study is also aimed to identify whether there is relationship readiness among the primary science teachers in terms of the share knowledge and skills, interest and attitudes with gender and teaching experience. A total of 115 teachers were involved in this study. The findings were obtained through a 5 likert scale questionnaire that aspects of teachers' readiness, interest, attitude and mastery of knowledge and skills The data was analysed by using the Statistical Package for Social Science (SPSS) version 20.0 and are shown in the frequency, percentage and mean. The studies show that aspects of teachers' skill, mastery of knowledge, interest and attitude are


in the high level. The T-test and ANOVA show that there are no significant between teachers' readiness in term of mastery of knowledge, skill, interest and attitude toward gender and teaching experience. Finally, the researchers made several recommendations for further studies which can be carried out by researchers in the future.

Keywords Knowledge, Skills, Interest, Attitude, Science, $21^{\text {st }}$ Century Learning.

\section{PENGENALAN}

Kementerian Pendidikan Malaysia (KPM) telah merangka Pelan Pembangunan Pendidikan Malaysia 2013 - 2025 (PPPM) bagi menyediakan murid menghadapi cabaran pendidikan abad ke-21 agar mampu bersaing pada peringkat antarabangsa. Sejajar dengan itu, dalam melahirkan keberhasilan dan kemenjadian murid, KPM telah melancarkan inisiatif pembelajaran abad ke-21 secara rintis pada tahun 2014 dan meluaskan pelaksanaan keseluruh negara mulai tahun 2015. Antara fokus PPPM yang ingin dicapai melalui pembelajaran abad ke-21 ialah enam (6) aspirasi murid iaitu pengetahuan, kemahiran berfikir, kemahiran memimpin, kemahiran dwibahasa, etika, kerohanian serta mempunyai identiti nasional. Ini adalah sejajar dengan Falsafah Pendidikan Kebangsaan (FPK) yang menumpukan pembangunan murid secara holistik yang menekankan pembangunan intelek, rohani, emosi dan fizikal, seiring dengan penghayatan identiti nasioal yang kukuh.

Namun begitu, keberkesanan pelaksanaan pembelajaran abad ke-21 tidak dapat tercapai sekiranya aspek keperluan tidak dititikberatkan. Pelaksanaan pembelajaran abad ke-21 berkait rapat dengan tiga keperluan utama iaitu persekitaran sekolah, reka bentuk bilik darjah dan kesediaan guru sebagai orang yang akan memimpin proses pembelajaran. Memandangkan guru merupakan agen pelaksana, kemahiran dan sikap guru merupakan elemen penting yang menjadi tunjang utama pelaksanaan kelas pembelajaran abad ke-21 jika dibandingkan dengan infrustruktur kelas itu sendiri (Ayub Ibrahim,2014).

Sehubungan dengan itu, dalam melaksanakan pembelajaran abad ke-21, kebolehan guru yang mampu berfikir, merancang, berbincang, menilai, mereka cipta dan membuatkan keputusan berlatarkan Model Partnership for $21^{\text {st }}$ Century (2015) amat diperlukan. Apa yang menjadi kekangan dalam kalangan guru sains ialah dari segi kefahaman, kemahiran dan kesediaan untuk memberi input dan menerapkan kemahiran-kemahiran yang diperlukan pada abad ke-21. Kedudukan pencapaian Malaysia dalam Trends in Mathmatics and Science Study (TIMSS) pada tahun 2015 pada kedudukan ke-22 Matematik dan kedudukan ke-24 bagi Sains daripada 49 buah negara. Ini jelas menunjukkan bahawa murid masih lagi tidak menguasai kemahirankemahiran abad ke-21. Berikutan dengan itu, guru yang merupakan tonggak utama kepada proses pembelajaran perlulah mempelbagaikan kaedah pengajaran dan pembelajaran yang memfokuskan kepada elemen-elemen kemahiran pemikiran kritikal, kemahiran kolaborasi, kemahiran komunikasi dan kreativiti bagi menjayakan pembelajaran abad ke-21. 
Justeru itu, kajian ini ingin meneroka gambaran keseluruhan tahap kesediaan khususnya guru sains terhadap pelaksanaan pembelajaran abad ke-21.

\section{OBJEKTIF KAJIAN}

Kajian ini adalah untuk mengkaji tahap kesediaan guru sains dari segi pengetahuan, kemahiran, minat dan sikap dalam melaksanakan pembelajaran abad ke-21. Secara spesifiknya objektif kajian ini adalah :

1. Mengenalpasti tahap kesediaan guru sains daripada aspek pengetahuan terhadap pelaksanaan pembelajaran abad ke-21.

2. Mengenalpasti tahap kesediaan guru sains daripada aspek kemahiran terhadap pelaksanaan pembelajaran abad ke-21.

3. Mengenalpasti tahap kesediaan guru sains daripada aspek minat terhadap pelaksanaan pembelajaran abad ke-21.

4. Mengenalpasti tahap kesediaan guru sains daripada aspek sikap terhadap pelaksanaan pembelajaran abad ke-21.

5. Mengenalpasti sama ada terdapat perbezaan tahap kesediaan guru sains dari aspek pengetahuan, kemahiran, minat dan sikap berdasarkan pengalaman mengajar.

\section{HIPOTESIS KAJIAN}

Ho1: Tidak terdapat perbezaan yang signifikan tahap kesediaan guru sains dari aspek pengetahuan, kemahiran, minat dan sikap berdasarkan pengalaman mengajar.

\section{KERANGKA KONSEPTUAL}

Kerangka teori kajian ini adalah berdasarkan model input-ouput. Merujuk kepada model Slavin (1994), guru merupakan faktor penyumbang kepada keberkesanan pengajaran dalam bilik darjah yang dipengaruhi oleh empat faktor iaitu kualiti pengajaran, kesesuaian aras pengajaran, insentif dan masa yang menjadi pembolehubah tidak bersandar sebagai input, manakala output pula dilihat dari aspek peningkatan dalam pencapaian pelajar yang berupa pembolehubah bersandar. Berdasarkan model ini, insentif merujuk kepada keupayaan guru dalam memberi motivasi kepada murid untuk terus belajar dan menyelesaikan tugasan yang diberi oleh guru. Masa pula membawa maksud tempoh waktu yang mencukupi untuk pelajar mempelajari sesuatu konsep atau kemahiran. 


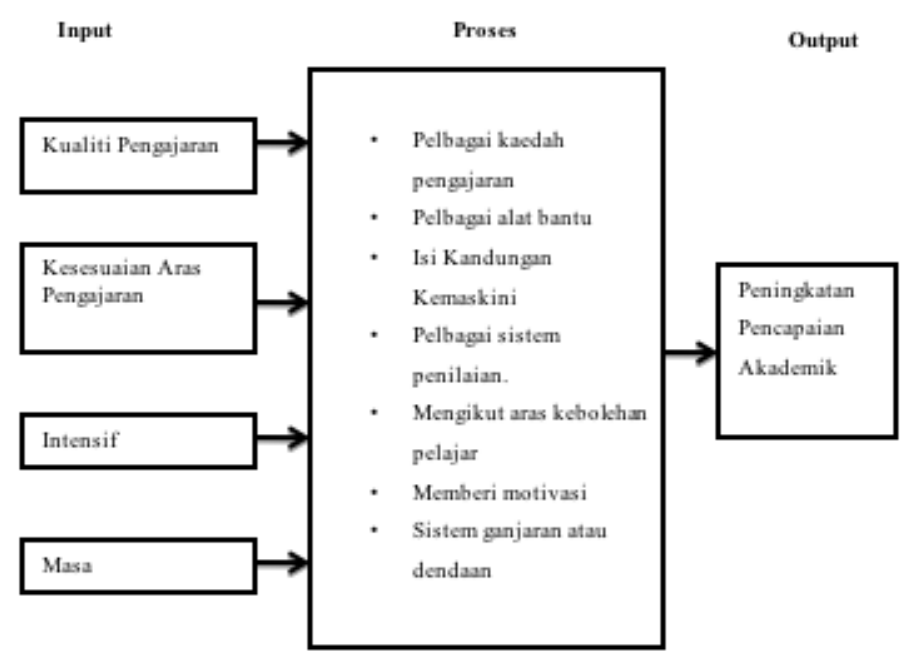

Rajah 1 Kerangka Teori Model Slavin

Sumber : Slavin (1994) A Theory of School and Classroom Organization

Berdasarkan ini, maka kerangka konsep kajian Rajah 1 diubahsuai dan diadaptasi daripada model pengajaran Slavin (1994) ini memperlihatkan satu proses kesediaan guru yang merangkumi sikap, minat, tahap pengetahuan dan tahap kemahiran yang berkait rapat sebagai orang yang akan memimpin proses pembelajaran. Guru juga dilihat sebagai keperluan perubahan ke arah pembelajaran abad ke-21 yang merupakan tunjang utama penggerak kepada pelaksanaan pembelajaran abad ke-21. Guru yang dilengkapi dengan pengetahuan dan kemahiran yang diperlukan untuk menghadapi perubahan ini, mampu memberi sumbangan kepada kejayaan pelaksanaan pembelajaran abad ke-21 di sekolah - sekolah.

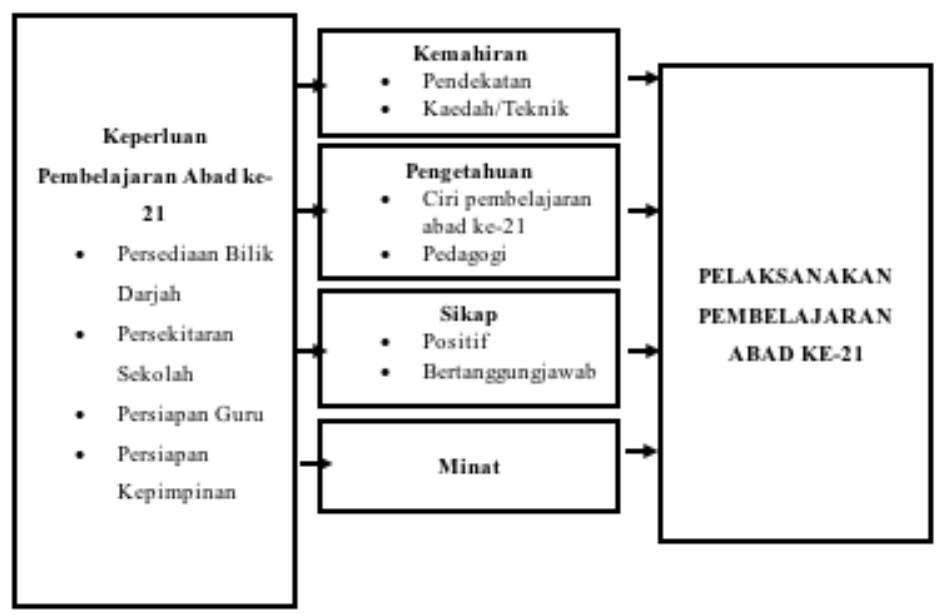

Rajah 2 Kerangka konsep kajian 


\section{TINJAUAN LITERATUR}

Dalam merealisasikan transformasi pendidikan abad ke-21 seperti dihasrat melalui Pelan Pembangunan Pendidikan Malaysia 2013-2025, guru yang berkualiti dan bersedia menghadapi cabaran menjadi sandaran Kementerian Pendidikan. Dapatan kajian bahawa peranan dan kualiti guru dalam melaksanakan pembelajaran abad ke21 amat besar kesannya terhadap keberhasilan murid sudah tidak dapat disangkalkan lagi.

Terdapat beberapa kajian yang telah dilaksanakan berkenaan pembelajaran abad ke-21 sejak reformasi ke arah pembelajaran abad ke-21 di semua sekolah pada tahun 2014. Namun begitu, terlalu sedikit kajian yang dilaksanakan yang menjurus kepada kesediaan pendidik dalam melaksananakan pembelajaran abad ke-21. Faridah Mariani et al., (2014) telah membuat kajian tentang tahap pemahaman dan amalan pengajaran kemahiran pensyarah di Kolej Vokasional Sungai Petani 1, Kedah Darul Aman. Sampel kajian melibatkan 36 orang pensyarah. Dapatan kajian mendapati tahap pengetahuan pensyarah terhadap kemahiran abad ke-21 adalah tinggi tetapi dari aspek strategi pengajaran mempunyai tahap yang sederhana sahaja. Ini berlaku kerana pensyarah masih lagi menggunakan kaedah pengajaran yang berpusatkan guru dengan memberikan nota dan kuliah.

Badrul Hisham (2016) pula telah mengkaji mengenai amalan pengajaran dan pembelajaran abad ke-21 dalam kalangan pensyarah Institut Pendidikan Guru Kampus Ipoh yang melibatkan 159 pensyarah dalam pelbagai opsyen. Hasil kajian mendapati bahawa tahap penguasaan kemahiran pengajaran abad ke-21 dalam kalangan pensyarah berada tahap rendah yang merangkumi kemahiran seperti pemikiran kritikal, refleksi, teknologi, kreativiti dan inovasi. Sebaliknya pula, kemahiran seperti komunikasi, kolaborasi, pentaksiran, dan penyelesaian masalah menunjukkan tahap penguasaan yang tinggi dalam kalangan pensyarah. Ini jelas menunjukkan bahawa terdapat lagi ruang-ruang penambaikan amalan proses pengajaran dan pembelajaran abad ke-21 yang perlu dipertingkatkan lagi dalam kalangan pensyarah.

Kajian-kajian terhadap kesediaan guru untuk melaksanakan pembelajaran abad ke21 turut dijalankan di luar negara. Antaranya dinyatakan oleh Barber dan Mourshed (2007) dalam bukunya How the World's Best Performing Systems Come Out on Top bahawa kualiti sesuatu sistem sekolah (pendidikan) tidak boleh melebihi kualiti gurunya. Hakikatnya bahawa kualiti individu guru itu sendiri terlebih dahulu perlu dipertingkatkan dari aspek komitmen dan kompetensi kerana ianya menjadi nadi dan penentu kepada sistem pendidikan sesebuah negara yang berjaya.

Begitu juga kajian mendapati Singapura turut melaksanakan perubahan yang drastik dari segi kurikulum, pedagogi, penilaian, teori - teori amalan hubungan, infrustruktur fizikal untuk melahirkan guru model pendidikan abad ke-21 yang perlu menguasai 21 kemahiran dengan menggunakan TE21 seperti mana yang dinyatakan oleh Lee (2012) sebagai "Addressing the concern that teachers themselves need to have $21^{\text {st }}$ century skills to teach those skills, the first of two pedagogical shifts is to increase "emphasis on selfdirected, inquiry-based, realworld learning".

Sehubungan dengan itu, Schrum dan Levin(2012) dalam kajiannya turut menyenaraikan tujuh perkara yang perlu ada dalam usaha pembentukan sekolah abad ke-21 seperti 
merangka dan melaksanakan visi, membentuk budaya sekolah, merancang dan melaksanakan penggunaan teknologi, merombak kurikulum dan amalan instruksional, pembangunan profesional guru, mendapatkan sumber kewangan untuk membiayai inisiatif dan berkolaborasi ibu bapa dan komuniti. Di mana pembangunan profesional guru turut menjadi elemen penting dalam melaksanakan pembelajaran abad ke-21 di sekolah.

Di Indonesia pula, sistem pembelajaran turut mengalami perubahan ke arah pembelajaran abad ke-21 yang dahulunya tidak berlandaskan kepada standard tetapi kini standard telah dijadikan acuan untuk mencapai tujuan pembelajaran. Bagi merealisasikan pembelajaran abad ke-21, Pendidikan Nasional abad ke-21 telah diperkenalkan di Indonesia yang merumuskan 16 prinsip pembelajaran yang harus dipatuhi dalam proses pendidikan abad ke-21 di mana salah satunya menekankan kepada keupayaan guru.

\section{METODOLOGI KAJIAN}

Kajian ini adalah kajian kuantitatif dengan menggunakan kaedah tinjauan. Kajian telah dijalankan di daerah Jasin, Melaka. Sampel kajian ini adalah seramai 123 orang guru sains sekolah rendah yang telah dipilih secara rawak daripada 488 orang populasi guru sains sekolah rendah yang mengajar di daerah Jasin.

Instrumen kajian ini diadaptasi dan diubahsuai daripada kajian oleh Rumaizah (2014) yang terbahagi kepada dua bahagian utama iaitu, Bahagian A dan Bahagian B. Instrumen Bahagian A berkenaan dengan latar belakang responden seperti jantina, umur, etnik, pengalaman mengajar, taraf akademik, lokasi, opsyen dan kursus dalam perkhidmatan. Bahagian B pula terdiri daripada skala "Likert" yang mengandungi lima pilihan iaitu (5) sangat setuju, (4) setuju, (3) tidak pasti, (2) tidak setuju, (1) sangat tidak setuju dan terbahagi kepada empat domain yang merangkumi Kesediaan Guru dari segi pengetahuan (10 item), kemahiran (8 item), sikap (15 item) dan minat (10 item). Jumlah kesemua item Kesediaan Guru yang dikaji ialah 43 item.

Dalam kajian ini, kesahan dan kebolehpercayaan instumen kajian disemak dengan cara menganalisis item-item dalam soal selidik dengan menggunakan perisian SSPS bagi mendapat nilai pekali Alpha Cronbach selepas kajian rintis dijalankan ke atas 20 orang guru sains. Analisis konstruk ini adalah penting dilakukan untuk memastikan konstruk - konstruk yang dipilih adalah benar-benar sesuai dan baik sebagai instrumen kajian.

Jadual 1 menunjukkan nilai Alpha Cronbach bagi setiap domain dan keseluruhan instrumen. Oleh kerana nilai kebolehpercayaan bagi semua pembolehubah yang terhasil daripada kajian rintis ini melebihi 0.6, maka instrumen kajian ini mempunyai ketekalan dan kebolehpercayaannya adalah boleh diterima. Ini kerana menurut Majid (1990) nilai Alfa Cronbach melebihi 0.6 sering kali diguna oleh pengkaji - pengkaji sebagai indek kebolehpercayaan dalam kajian. 
Jadual 1 Nilai Alpha Cronbach Pemboleh ubah kajian

\begin{tabular}{lll}
\hline Pembolehubah & Bilangan item & Nilai Alpha Cronbach \\
\hline Pengetahuan & 10 & 0.904 \\
Kemahiran & 8 & 0.91 \\
Minat & 11 & 0.881 \\
Sikap & 13 & 0.83 \\
\hline
\end{tabular}

Analisis data dilakukan bertujuan untuk menyusun data dalam kaedah yang bermakna supaya dapat difahami. Untuk menentukan tahap kesediaan guru dari segi pengetahuan, kemahiran, minat dan sikap dalam pelaksanaan pembelajaran abad ke-21, statistik deskriptif digunakan dengan mencari nilai min dan peratusan. Statistik inferensi pula digunakan untuk melihat perkaitan di antara dua pembolehubah dan digunakan untuk menguji hipotesis. Kaedah statistik yang digunakan dalam kajian ini terdiri dari ujian - t dan Ujian ANOVA sehala.

\section{DAPATAN KAJIAN}

\section{Dapatan Statistik Deskriptif}

Bahagian ini membincangkan dapatan statistik deskriptif. Perbincangan dapatan adalah mengikut objektif kajian.

1. Tahap kesediaan guru-guru sains dari segi pengetahuan dalam melaksanakan pembelajaran abad ke -21 .

Jadual 2 Kesediaan Guru Dari Segi Pengetahuan

\begin{tabular}{|c|c|c|c|}
\hline Item & Min & $\mathrm{Sp}$ & Interpretasi \\
\hline $\begin{array}{l}\text { 1. Saya mempunyai pengetahuan bagi mengajar Sains } \\
\text { dengan mengaplikasikan pembelajaran abad ke- } 21 \\
\text { di dalam kelas. }\end{array}$ & 4.02 & .546 & Tinggi \\
\hline $\begin{array}{l}\text { 2. Saya berkelayakan untuk mengajarkan subjek Sains } \\
\text { dengan berkesan. }\end{array}$ & 4.09 & .523 & Tinggi \\
\hline $\begin{array}{l}\text { 3. Saya mempunyai kefahaman yang jelas tentang } \\
\text { setiap topik dan item. }\end{array}$ & 4.09 & .488 & Tinggi \\
\hline $\begin{array}{l}\text { 4. Saya mempunyai pengetahuan untuk memotivasikan } \\
\text { murid belajar subjek Sains. }\end{array}$ & 4.17 & .566 & Tinggi \\
\hline $\begin{array}{l}\text { 5. Saya mempunyai pengetahuan untuk meningkatkan } \\
\text { penguasaan murid dalam subjek Sains. }\end{array}$ & 4.14 & .544 & Tinggi \\
\hline $\begin{array}{l}\text { 6. Saya mempunyai pengetahuan dalam menggunakan } \\
\text { pelbagai kaedah pengajaran dan pembelajaran bagi } \\
\text { menarik minat murid. }\end{array}$ & 4.05 & .510 & Tinggi \\
\hline $\begin{array}{l}\text { 7. Saya sentiasa bersedia untuk berkongsi pengetahuan } \\
\text { dengan guru-guru lain tentang sukatan pelajaran } \\
\text { subjek Sains. }\end{array}$ & 4.12 & .401 & Tinggi \\
\hline
\end{tabular}


8. Saya mempunyai pengetahuan dalam menyampaikan ilmu sains kepada murid.

9. Saya mempunyai pengetahuan untuk mengendalikan ujian-ujian mengikut tahap pentafsiran yang ditetapkan dalam DSKP sains.

10. Saya perlu belajar untuk menambah pengetahuan tentang pelaksanaan pembelajaran abad ke- 21 .

\section{$\begin{array}{lll}4.24 & .488 \quad \text { Tinggi }\end{array}$}

$\begin{array}{lll}3.89 & .659 & \text { Tinggi }\end{array}$

4.48 $\quad .612 \quad$ Tinggi

Skor Purata

4.13

.348

Tinggi

Jadual 2 menunjukkan tahap kesediaan guru dari segi pengetahuan. Pada keseluruhannya tahap kesediaan guru dari segi pengetahuan berada pada tahap tinggi dengan min keseluruhannya ialah 4.13 dan sisihan piawai ialah .348. Semua item memberikan skor min pada tahap tinggi iaitu di antara julat min 3.89 hingga 4.48. Item 10 iaitu "saya perlu belajar untuk menambah pengetahuan tentang pelaksanaan pembelajaran abad ke-21" memberikan dapatan min pada paling tinggi $(\mathrm{min}=4.48$ $\mathrm{sp}=.612$ ) manakala min paling rendah di antara kesemua item aspek pengetahuan ialah item 9 iaitu "saya mempunyai pengetahuan untuk mengendalikan ujian-ujian mengikut tahap pentafsiran yang ditetapkan dalam DSKP sains" ( $\min =3.89$ dan $\mathrm{sp}$ $=.659)$.

2. Tahap kesediaan guru-guru sains dari segi kemahiran dalam melaksanakan pembelajran abad ke -21

Jadual 3 Kesediaan Guru Dari Segi Kemahiran

\begin{tabular}{|c|c|c|c|}
\hline Item & Min & $\mathrm{Sp}$ & Interpretasi \\
\hline $\begin{array}{l}\text { 1. Saya mempunyai kemahiran dalam mempraktikkan } \\
\text { pembelajaran abad ke-21 bagi mengajar subjek Sains. }\end{array}$ & 3.85 & .534 & Tinggi \\
\hline $\begin{array}{l}\text { 2. Saya mempunyai kemahiran untuk memotivasikan murid } \\
\text { supaya seronok belajar Sains. }\end{array}$ & 3.87 & .682 & Tinggi \\
\hline $\begin{array}{l}\text { 3. Saya mempunyai kemahiran mengajarkan subjek sains } \\
\text { dengan menggunakan teknik mudah. }\end{array}$ & 3.83 & .775 & Tinggi \\
\hline $\begin{array}{l}\text { 4. Saya mempunyai kemahiran dalam mengaplikasikan } \\
\text { strategi pembelajaran dalam kelas. }\end{array}$ & 3.94 & .692 & Tinggi \\
\hline $\begin{array}{l}\text { 5. Saya mempunyai kemahiran dalam mengendalikan } \\
\text { penggunaan bahan bantu mengajar bagi melancarkan } \\
\text { pengajaran dan pembelajaran. }\end{array}$ & 4.15 & .566 & Tinggi \\
\hline $\begin{array}{l}\text { 6. Saya sentiasa bersedia untuk berkongsi kemahiran } \\
\text { dengan guru-guru lain tentang sukatan pelajaran Sains. }\end{array}$ & 4.03 & .504 & Tinggi \\
\hline $\begin{array}{l}\text { 7. Saya mempunyai kemahiran penggunaan komputer } \\
\text { dalam proses pengajaran dan pembelajaran. }\end{array}$ & 3.94 & .551 & Tinggi \\
\hline
\end{tabular}


8. Saya berkemahiran membuat analisis pencapaian murid mengikut tahap tafsiran yang telah ditetapkan dalam $3.71 \quad .542 \quad$ Tinggi DSKP Sains.

$\begin{array}{lllll}\text { Skor } & \text { Purata } & 3.91 & .385 & \text { Tinggi }\end{array}$

Jadual 3 menunjukkan tahap kesediaan guru dari segi kemahiran. Pada keseluruhannya tahap kesediaan guru dari segi kemahiran berada pada tahap tinggi dengan min keseluruhannya ialah 3.91 dan sisihan piawai ialah .385. Semua item memberikan skor min pada tahap tinggi iaitu di antara julat min 3.71 hingga 4.15. Item 5 iaitu "saya mempunyai kemahiran dalam mengendalikan penggunaan bahan bantu mengajar bagi melancarkan pengajaran dan pembelajaran" memberikan dapatan min pada paling tinggi $(\mathrm{min}=4.15 \mathrm{sp}=.566)$ manakala min paling rendah di antara kesemua item aspek kemahiran ialah item 8 iaitu "saya berkemahiran membuat analisis pencapaian murid mengikut tahap tafsiran yang telah ditetapkan dalam DSKP Sains $(\min =3.89$ dan $\mathrm{sp}=.659)$.

3. Tahap kesediaan guru-guru Sains dari segi sikap dalam perlaksanakan pembelajaran abad ke-21

Jadual 4 Kesediaan Guru Dari Segi Sikap

\begin{tabular}{lccc}
\hline Bil Item & Min & Sp & Interpretasi \\
\hline $\begin{array}{l}\text { 1. Saya berasa selesa mengajarkan Sains semenjak } \\
\text { pembelajaran abad-21 diperkasakan. }\end{array}$ & 3.93 & .525 & Tinggi \\
$\begin{array}{l}\text { 2. Saya lebih yakin mengajar Sains di dalam kelas dengan } \\
\quad\end{array}$ & 3.77 & .547 & Tinggi
\end{tabular}

3. Saya membuat persediaan rapi sebelum mengajar bagi memastikan pengajaran berjalan dengan lancar dan $4.05 \quad .436 \quad$ Tinggi berkesan.

4. Saya membuat persediaan rapi dalam penyediaan bahan bantu mengajar agar pembelajaran lebih berkesan.

$4.10 \quad .484 \quad$ Tinggi

5. Saya merujuk kepada sukatan pelajaran bagi memastikan pemahaman dalam penyampaian ilmu pengajaran mengikut kehendak kurikulum.

$4.25 \quad .475 \quad$ Tinggi

6. Saya sentiasa membuat inovasi dalam pengajaran dan pembelajaran Sains selaras dengan sukatan pelajaran yang diperkenalkan.

$\begin{array}{lll}3.75 & .647 \quad \text { Tinggi }\end{array}$

7. Saya membuat kajian tindakan mengenai kebolehan murid bagi memastikan penilaian terhadap murid $3.64 \quad .752 \quad$ Sederhana berkesan. 
8. Saya bersedia untuk mengikuti kursus pemantapan

pengajaran dan pembelajaran bagi memantapkan lagi

$\begin{array}{lll}4.43 & .530 \quad \text { Tinggi }\end{array}$

pengetahuan saya.

9. Saya bersedia untuk mengikuti kursus berkaitan

berkaitan subjek Sains demi meningkatkan kemahiran

$\begin{array}{lll}4.32 & .629 \quad \text { Tinggi }\end{array}$ saya.

10. Saya berbincang dengan rakan sekerja bagi membuat refleksi isi kandungan pengajaran dan pembelajaran

$\begin{array}{lll}4.08 & .480 \quad \text { Tinggi }\end{array}$
Sains.

11. Perlaksanaan dan memperkasakan pembelajaran abad ke-21 menimbulkan masalah kepada guru.

$3.29 \quad .803 \quad$ Sederhana

12. Saya kerap terlibat dalam mesyuarat, taklimat dan aktiviti- aktiviti berkaitan Sains di sekolah.

$3.54 \quad .741 \quad$ Sederhana

13. Saya selalu menganalisis pencapaian murid untuk tindakan susulan.

$3.84 \quad .470 \quad$ Tinggi

Skor Purata

$\begin{array}{lll}3.92 & \text {.243 } & \text { Tinggi }\end{array}$

Jadual 4 menunjukkan tahap kesediaan guru dari segi sikap. Pada keseluruhannya tahap kesediaan guru dari segi sikap berada pada tahap tinggi dengan min keseluruhannya ialah 3.92 dan sisihan piawai ialah .234. Skor min pada tahap tinggi diperoleh bagi item $1,2,3,4,5,6,8,9,10$ dan 13. Manakala skor min pada tahap sederhana ialah bagi item 7,11 dan 12. Item 8 iaitu "saya bersedia untuk mengikuti kursus pemantapan pengajaran dan pembelajaran bagi memantapkan lagi pengetahuan saya" mempunyai min yang paling tinggi $(\mathrm{min}=4.43$ dan $\mathrm{sp}=.530)$ manakala min yang paling rendah ialah item 11 iaitu "pelaksanaan dan memperkasakan pembelajaran abad ke-21 menimbulkan masalah kepada guru" $(\min =3.29$ dan $\mathrm{sp}=0.803)$. Dapatan kajian menunjukkan guru Sains di daerah Jasin memiliki tahap sikap yang tinggi dalam perlaksanaan pembeajaran abad ke-21.

4. Tahap kesediaan guru-guru Sains dari segi minat dalam perlaksanakan pembelajaran abad ke-21

Jadual 5 Kesediaan Guru Dari Segi Minat

\begin{tabular}{lllll}
\hline Bil Item & Min & Sp & Interpretasi \\
\hline 1. Saya sangat berminat untuk mengajar subjek Sains. & 4.35 & .531 & Tinggi
\end{tabular}

2. Saya sangat berminat mengajar kelas dengan subjek

Sains kerana ini merupakan satu cabaran bagi memenuhi

$\begin{array}{lll}4.11 & .574 \quad \text { Tinggi }\end{array}$

kehendak matlamat pembelajaran abad ke -21 .

3. Saya menawarkan diri untuk mengajar Sains di dalam

kelas dengan mempraktikkan pembelajaran abad ke-21

$\begin{array}{lll}3.89 & .698 \quad \text { Tinggi }\end{array}$

kerana minat mendalam terhadap subjek saya. 
4. Saya berminat mengajar subjek Sains kerana pengalaman yang ada pada saya.

$4.26 \quad .531 \quad$ Tinggi

5. Saya berpuas hati semasa mengajar subjek Sains dengan menerapkan pembelajaran abad ke-21.

$3.89 \quad .526 \quad$ Tinggi

6. Saya dapat menyebarkan kurikulum baharu dengan mudah kerana memahami isi kandungan.

$3.79 \quad .521 \quad$ Tinggi

7. Saya berminat mengajar Sains apabila pembelajaran abad ke -21 sudah mula diperkasakan di sekolah saya.

$3.75 \quad .590 \quad$ Tinggi

$4.10 \quad .675 \quad$ Tinggi mengikuti kursus subjek sains di Institut.

9. Saya berminat mengajar Sains kerana ini merupakan subjek pilihan utama saya.

$\begin{array}{lll}4.21 & .521 \quad \text { Tinggi }\end{array}$

10. Saya berminat mengajar Sains kerana dapat menggunakan pelbagai bentuk strategi pengajaran dan pembelajaran.

11. Saya berminat mengajar Sains kerana merupakan cabaran kepada saya.

$4.17 \quad 517 \quad$ Tinggi

Skor Purata

$\begin{array}{lll}4.18 & .539 \quad \text { Tinggi }\end{array}$

\section{Skor Purata}

Jadual 5 menunjukkan tahap kesediaan guru dari segi minat. Pada keseluruhannya tahap kesediaan guru dari segi minat berada pada tahap tinggi dengan min keseluruhannya ialah 4.06 dan sisihan piawai ialah .357. Semua item memberikan skor min pada tahap tinggi iaitu di antara julat min 3.75 hingga 4.35. Item 1 iaitu "saya berminat untuk mengajar subjek Sains" memberikan dapatan min pada paling tinggi $(\mathrm{min}=4.35 \mathrm{sp}$ $=.531$ ) manakala min paling rendah di antara kesemua item aspek minat ialah item 7 iaitu "saya amat berminat mengajar Sains apabila pembelajaran abad ke-21 mula diperkasakan di sekolah saya" $(\min =3.75$ dan $\mathrm{sp}=.590)$.

\section{Dapatan statistik inferensi}

Bahagian ini membincangkan dapatan statistik inferensi yang dijalankan untuk menjawab persoalan 5 iaitu adakah terdapat perbezaan kesediaan dari segi pengetahuan, kemahiran, minat dan sikap berdasarkan jantina dan pengalaman mengajar.

Ho:

Tidak terdapat perbezaan yang signifikan antara kesediaan guru sains dari aspek penguasaan pengetahuan, kemahiran, minat dan sikap dengan jantina dan pengalaman mengajar dalam melaksanakan pembelajaran abad ke-21. 
Jadual 6 Keputusan Ujian-t bagi Perbezaan Kesediaan antara Guru Sains Lelaki dan Perempuan dalam Pelaksanaan Pembelajaran Abad ke-21

\begin{tabular}{lcccc}
\hline Kesediaan & Lelaki & Perempuan & nilai- t & Nilai-p. \\
\cline { 2 - 3 } Pengetahuan & Min (SP) & Min (SP) & & \\
Sikap & $4.14(0.33)$ & $4.12(0.35)$ & 0.227 & 0.821 \\
Kemahiran & $3.97(0.25)$ & $3.91(0.23)$ & 0.996 & 0.322 \\
$\begin{array}{l}\text { Minat } \\
\text { Kesediaan }\end{array}$ & $3.89(0.58)$ & $3.92(0.32)$ & -0.316 & 0.752 \\
Keseluruhan & $4.09(0.35)$ & $4.06(0.36)$ & 0.414 & 0.680 \\
\hline
\end{tabular}

Nota.ts $=$ tidak signifikan, $\mathrm{p}>.05$

Jadual 6 menunjukkan keputusan analisis Ujian-t untuk melihat perbezaan kesediaan guru Sains daripada segi pengetahuan, sikap, kemahiran dan minat berdasarkan jantina guru iaitu perempuan dan lelaki dalam perlaksanaan pembelajaran abad ke21. Hasil dapatan secara terperinci menunjukkan bahawa guru lelaki mempunyai kesediaan yang lebih tinggi $(\min =4.14)$ dari aspek pengetahuan berbanding dengan guru perempuan $(\min =4.12)$. Selain itu, dapatan juga menunjukkan guru lelaki mempunyai kesediaan yang lebih tinggi $(\min =4.09)$ dari aspek minat berbanding dengan guru perempuan $(\min =4.09)$. Sebaliknya guru perempuan memperoleh skor min yang lebih tinggi dalam aspek sikap dan kemahiran. Namun perbezaan-perbezaan skor min bagi aspek pengetahuan, sikap, kemahiran dan minat adalah tidak signifikan seperti yang ditunjukkan dalam Jadual 6. 
Jadual 7 Keputusan Ujian ANOVA sehala bagi Perbezaan Min Kesediaan dalam Pelaksanaan Pembelajaran Abad ke-21 mengikut Pengalaman Mengajar

\begin{tabular}{|c|c|c|c|c|c|c|}
\hline & & $\begin{array}{c}\text { Jumlah } \\
\text { Kuasa Dua }\end{array}$ & df & $\begin{array}{c}\text { Min } \\
\text { Kuasa } \\
\text { Dua }\end{array}$ & F & Nilai-p \\
\hline \multirow[t]{2}{*}{ Pengetahuan } & Antara Kumpulan & .442 & 2 & .221 & 1.849 & .162 \\
\hline & Dalam Kumpulan & 13.374 & 112 & .119 & & \\
\hline \multirow[t]{3}{*}{ Sikap } & Antara Kumpulan & .171 & 2 & .085 & 1.574 & .212 \\
\hline & Dalam & 6.078 & 112 & .054 & & \\
\hline & Kumpulan & & & & & \\
\hline \multirow[t]{2}{*}{ Kemahiran } & Antara Kumpulan & .214 & 2 & .107 & .718 & .490 \\
\hline & Dalam Kumpulan & 16.704 & 112 & .149 & & \\
\hline \multirow[t]{2}{*}{ Minat } & Antara Kumpulan & .036 & 2 & .018 & .137 & .872 \\
\hline & Dalam Kumpulan & 14.513 & 112 & .130 & & \\
\hline
\end{tabular}

Nota.ts $=$ tidak signifikan, $\mathrm{p}>.05$

Dapatan kajian menunjukkan bahawa tidak terdapat perbezaan signifikan kesediaan secara keseluruhan antara tiga kategori pengalaman mengajar guru sains. Jadual 7 menunjukkan keputusan ujian ANOVA sehala bagi setiap aspek kesediaan iaitu pengetahuan, sikap, kemahiran dan minat dalam pelaksanaan pembelajaran abad ke-21 berdasarkan kategori pengalaman mengajar guru. Analisis hasil dapatan secara lebih mendalam menunjukkan tidak terdapat perbezaan signifikan dari aspek pengetahuan $(\mathrm{p}=.162)$, sikap $(\mathrm{p}=.212)$, kemahiran $(\mathrm{p}=.490)$ dan minat $(\mathrm{p}=.872)$ dalam pelaksanaan pembelajaran abad ke-21 antara kategori pengalaman mengajar. Ini memandangkan kerana nilai signifikan untuk keempat-empat aspek kesediaan adalah melebihi nilai $\mathrm{p}>.05$. Jadi dapatlah disimpulkan bahawa hipotesis kajian ini diterima iaitu tidak terdapat perbezaan yang signifikan antara pengetahuan, sikap, kemahiran dan minat dengan pengalaman mengajar guru Sains dalam perlaksanaan pembelajaran abad ke-21.

\section{KESIMPULAN}

Secara keseluruhannya, hasil kajian menunjukkan tahap kesediaan guru sains dari aspek pengetahuan, sikap, kemahiran dan minat tanpa mengira jantina dan pengalaman guru mengajar adalah berada pada tahap yang tinggi. Ini dapat disimpulkan bahawa guru sains di daerah Jasin bersedia untuk melaksanakan pembelajaran abad ke-21 yang kini baru sahaja memasuki jangka masa empat tahun semenjak diperkenalkan secara rintis di semua sekolah pada tahun 2014. 
Hasil daripada keputusan kajian ini memberikan implikasi petunjuk bahawa guru sains mempunyai kesediaan yang baik daripada aspek pengetahuan, sikap, kemahiran dan minat dalam melaksanakan pembelajaran abad ke -21 dalam bilik darjah. Selaras dengan persiapan guru sebagai keperluan utama perubahan ke arah pembelajaran abad ke-21, dapatan kajian ini dapat menjadi penanda aras bahawa pembelajaran abad ke-21 boleh diterapkan dan dilaksanakan oleh semua guru di semua sekolah. Dalam pada itu, dalam merangka kurikulum dan melakukan anjakan dalam sistem pendidikan ke arah abad ke-21, penilaian ke atas golongan guru tidak harus diabaikan. Golongan guru juga perlu dinilai bagi memastikan guru benar-benar bersedia dalam memikul pelaksanaan sistem pembelajaran yang diharapkan.

Pembelajaran abad ke-21 yang telah lama diperkenalkan dalam PPPM 2013-2015 selaras dengan pelaksanaan kurikulum baru iaitu KSSR yang bermula pada tahun 2011, adalah merupakan satu usaha murni Kementerian Pelajaran Malaysia bagi mencapai enam aspirasi murid yang terkandung dalam PPPM 2013-2015. Namun begitu, dalam mencapai matlamat tersebut, pembentukan pendidikan abad ke-21 amatlah diperlukan sebagaimana yang telah dilaksanakan di negara-negara jiran yang lain. Oleh yang demikian, di bahu para pendidik yang merupakan tonggak pelaksana kepada hasrat yang diharapkan. Guru-guru bukan sahaja di peringat rendah dan malahan di peringkat institusi tinggi perlulah bersedia dari segala aspek dan sentiasa bersedia untuk memperlengkapkan diri dengan pengetahuan dan kemahiran yang menjurus kepada bidang pendidkan. Hal ini kerana apabila guru-guru mempunyai tahap kesediaan yang tinggi daripada aspek pengetahuan, kemahiran dan afektif, guru-guru akan lebih bermotivasi untuk melaksanakan tugas dan tanggungjawab mereka. Ini secara tidak langsung dapat membantu kepada pelaksanaan pembelajaran abad ke-21 dengan jayanya di dalam bilik darjah.

\section{RUJUKAN}

Ayub Ibrahim. 2014. Kelas Pembelajaran Abad Ke-21 [Slaid PowerPoint]. Diperolehi dari http://www.slideshare.net/mpsmcawanganmelaka/abad-ke-21?related $=2[8$ Januari 2018]

Aznita Johan. (2014). Kesediaan Guru Matematik dalam Mengimplemantasi Kurikulum Matematik Standard Sekolah Rendah di Daerah Johor Bharu. Universiti Teknologi Malaysia, Skudai.

Akhbar Ibrahim \& Siti Zaliha Reduan. (2002). Penilaian prestasi berasaskan sekolah: Pelaksanaan dan kesediaan guru. Kertas kerja dibentangkan di Persidangan Kebangsaan Penilaian Kemajuan Berasaskan Sekolah, Universiti Sains Malaysia, Pulau Pinang.

Bahagian Sekolah (2017). Buku Panduan Pelaksanaan Pembelajaran Abad ke-21. Kementerian Pendidikan Malaysia.

Bahagian Pembangunan Kurikulum Kementerian Pendidikan Malaysia. 2014 Program For International Student Assessment (PISA). file://C:/Users/wani/ Downloads/slot_i latar_belakang_pencapaian_pisa_insiatiflb[15 Januari 2018] 
Badrul Hisham Alang Osman. (2016). Amalan pengajaran dan pembelajaran abad ke-21 dalam kalangan pensyarah Institut Pendidikan Guru Kampus Ipoh. Jurnal Penyelidikan Dedikasi Jilid 10.

Behar-Horenstein, L. S., \& Niu, L. (2011). Teaching Critical Thinking Skills In Higher Education: A Review Of The Literature. Journal of College Teaching and Learning, 8(2), 25-41.

Creswell, J. W., (2008). Educational Research. New Jersey: Pearson-Merrill Prentice Hall.

Cronbach, L. J. (1946). RCreswell, J. W. (2002). Educational research - planning, conducting, and evaluating quantitative and qualitative research ( $2 \mathrm{nd} \mathrm{Ed}) . \mathrm{New}$ Jersey: Pearson Merril Prentice Hall.

Chua Yan Piaw, (2009). Statistik Penyelidikan Lanjutan: Ujian Regresi, Analisis Faktor dan Analisis SEM. Kuala Lumpur: McGraw Hill Sdn. Bhd.

Faridah Mariani Johari, Norlia Abd Aziz, Widad Othman, Hirul Nizam dan Zainuddin Md Isa. (2014). Amalan Pengajaran Kemahiran Abad ke-21 Di Kolej Sungai Petani 1, Kedah Darul Aman, Malaysia. Proceedings the $8^{\text {th }}$ International Conference on Indonesia-Malaysia Relations, Pekan Baru, 23-25 September 2014.

Lee, S.K. (2012, March 14-15). Preparing 21st century teachers: Singapore's approach. New York, NY: International Summit on the Teaching Profession.

Mohd Majid Konting. (1990). Kaedah penyelidikan pendidikan. Kuala Lumpur: Dewan Bahasa dan Pustaka.

NIE. (2009). A Teacher Education Model for the 21 st Century. A Report by the National Institute of Education. Nanyang Institute of Education. Singapore: Nanyang Institute.

Nooraini Abdul Rahim dan Abdul Halim bin Abdullah. (2016). Kesediaan Guru Sekolah Menengah Dalam Melaksanakan Proses Pnegajaran dan Pembelajaran Abad ke-21. Skudai: Universiti Teknologi Malaysia.

Norazilawati Abdullah, Noraini Mohd Noh, Mahizer Hamzah, Nik Azmah Nik Yusuf \& Rumaizah Omar. (2014). Kesediaan Guru Sains dan Matematik dalam Pelaksanaan Kurikulum Standard Sekolah Rendah. Jurnal Pendidikan Sains dan Matematik, 4(1), pp.81-86

Rumaizah Omar (2014). Kesediaan Guru Sains dan Matematik dalam Pelaksanaan Kurikulum Standard Sekolah Rendah. Universiti Pendidikan Sultan Idris.

Schrum, L., Levin, B.B. (2012). Evidence-based Strategies for leading 21st century schools. Saga Publications.

Van Dalen, D. B. (1993). Memahami penyelidikan satu pengenalan. (Terjemahan Abd Fatah Abdul Malik \& Mohd Majid Konting) Selangor: Universiti Pertanian Malaysia.

Witt, R., \& Orvis, J. (2010). A guide to becoming a school of the future. National Association of Independent schools. Retrieved 8 January, 2017 from https:// www.nais.org/articles/documents/naiscoaschools.pdf 
Yahya Buntat, Muhammad Rashid Rajuddin, Kandar Selamat \& Muhammad Syukri Saud. (2003). Kesesuaian kurikulum mata pelajaran Kemahiran Hidup Pertanian Fakulti Pertanian Universiti Teknologi Malaysia terhadap keperluan di sekolah, Jabatan Pendidikan Kejuruteraan dan Teknikal. Laporan Akhir Penyelidikan. Fakulti Pendidikan, Universiti Teknologi Malaysia, Skudai. 